$\mathrm{Oz}$

Volume 28

Article 4

$1-1-2006$

\title{
Trailer Wrap: Re-Fabricating Manufactured Housing
}

Michael Hughes

Bruce Wrightsman

Follow this and additional works at: https://newprairiepress.org/oz

(c) (i) $\Theta \Theta$

This work is licensed under a Creative Commons Attribution-Noncommercial-No Derivative Works 4.0 License.

\section{Recommended Citation}

Hughes, Michael and Wrightsman, Bruce (2006) "Trailer Wrap: Re-Fabricating Manufactured Housing," Oz: Vol. 28. https://doi.org/10.4148/2378-5853.1429

This Article is brought to you for free and open access by New Prairie Press. It has been accepted for inclusion in Oz by an authorized administrator of New Prairie Press. For more information, please contact cads@k-state.edu. 


\section{Trailer Wrap}

Re-Fabricating Manufactured Housing

\section{Michael Hughes and Bruce Wrightsman}

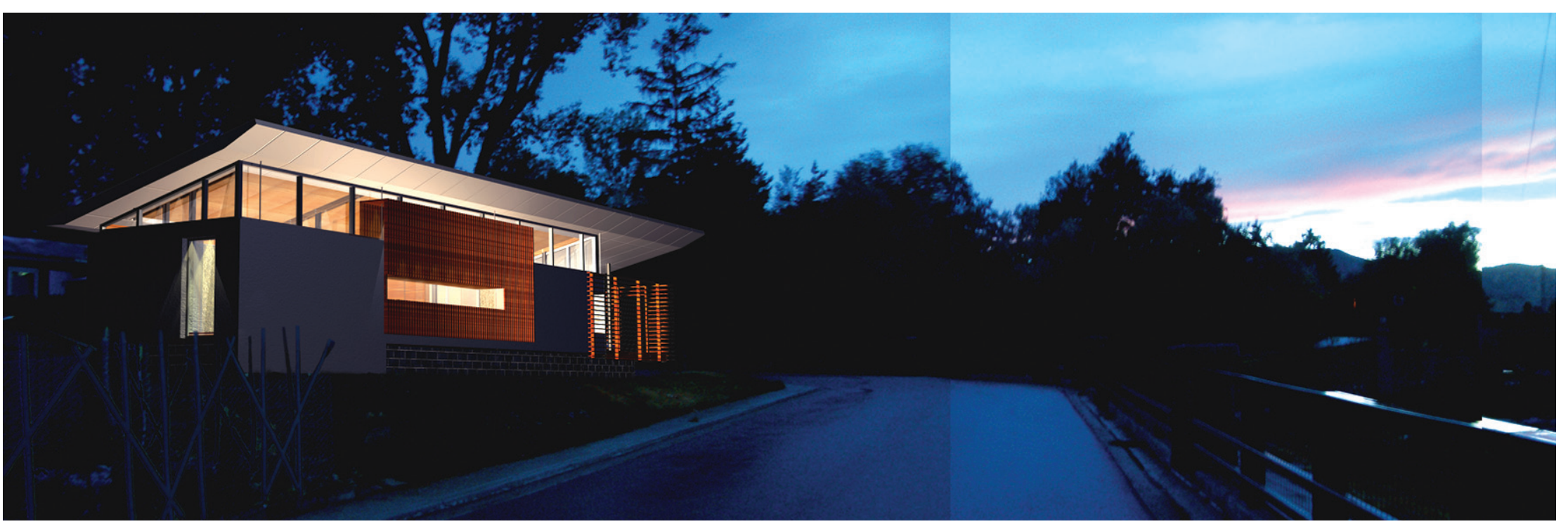

TrailerWrap is an innovative, community design/build project focused on engaging students in issues of sustainable and affordable design in the context of the trailer park. At the scale of an individual building the project explores the potential for providing affordable housing through the adaptive reuse and recycling of old, inefficient mobile homes. At the urban scale the project reexamines the mobile home park as a model for equitable, high-density urban planning alternatives to suburban sprawl. In pushing the envelope of sustainable reuse, the TrailerWrap project seeks to create exciting, small scale, high density, and affordable architecture with a social and environmental
Often overlooked or looked down upon, the ubiquitous mobile home constitutes an important but under-appreciated housing typology that serves a wide range of citizens. Since the mid-1900s mobile homes and manufactured housing have been mass produced in an attempt to provide a low cost housing. In doing so, several important factor that make a house a home have been overlooked. Unimaginative aesthetic and spatial design combined with inefficient energy strategies and poor construction techniques define the major shortcomings common in the industry. These conditions make these homes difficult to maintain, leading to extreme conditions of disrepair and often abandonment. TrailerWrap strives to provide simple and afford- able solutions that improve both the spatial quality and energy efficiency typically found in conventional manufactured housing.

Beyond the individual housing unit, land use patterns established in the familiar trailer park provide a uniquely American urban planning mode combining relatively high density with individual land ownership. As such, the urban mobile home park constitutes a rare opportunity for people of minimal or modest income to live in the center of town, close to jobs, retail, and entertainment. In terms of both scale and cost, the trailer park fills an underserved niche in spectrum of contemporary housing options. Slotted between the typical suburban quarter-acre lot and the multi-unit condominium/apartment complex, the standard 25 foot by 75 foot mobile home lot offers a single-family option, complete with its own plot of land, at an affordable price.

Diverted on its way to the landfill a cramped, 11 foot by 47 foot, twobedroom donor trailer at the heart of TrailerWrap is now being transformed into an open, expansive example of small-scale architecture. Conceived as a single, loft-like volume oriented toward a new outdoor room, the project privileges experiential conditions that affect the immediate scale of human occupation. The spatial organization compresses functional utility into dense, multipurpose zones 


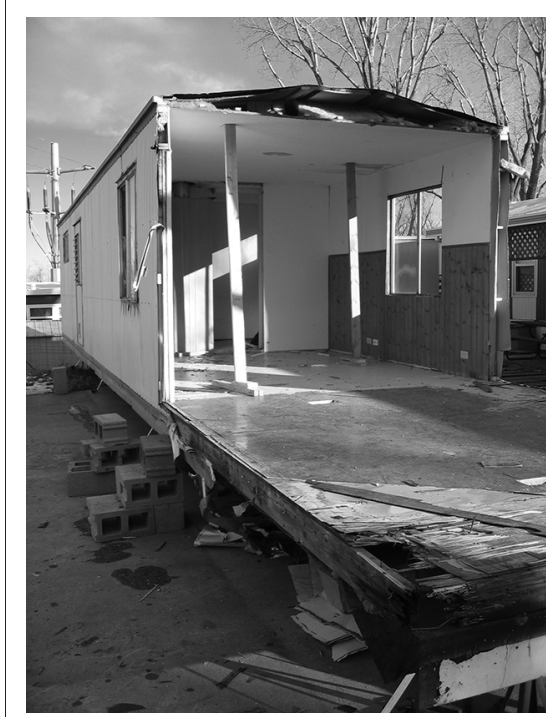

Donated trailer
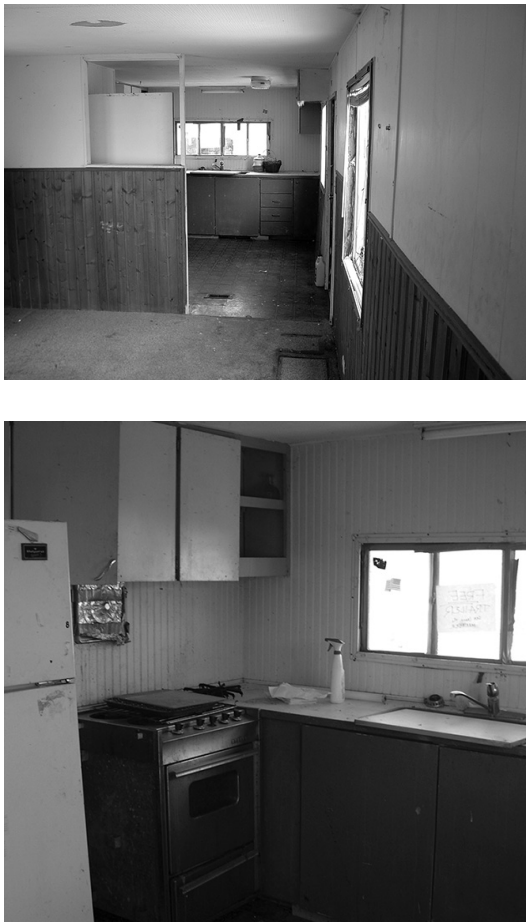

that dissolve boundaries typically associated with specific, partitioned rooms. Similarly, the high ceiling of the interior extends out to define and incorporate the occupiable landscape. Programmatically, this extension takes advantage of the surprisingly temperate local climate and expands the public space in the house, both visually and functionally.

This interwoven sensibility begins with a site strategy that links building and site through placement and circulation. The resulting hybrid mixes the linear character of the trailer with a processional sequence and social space more common in traditiona houses with large yards and gracious front porches. This unobstructed path celebrates the relationship between the interior and exterior while a series of subtle thresholds mark transitions and modulate the formal procession from the more public character on the front, west side to the relatively private space of the rear, east side.

Organizing the interior a thick, freestanding wall houses aspects of the bathroom and kitchen along with storage and the dining room table while simultaneously defining the four main spaces of the interior. Following the adaptive reuse principles at work in the overall project, a framework of salvaged solid-core doors structure the thick wall and frame cabinet openings in addition to serving as the dining table surface. The mono-pitch shed

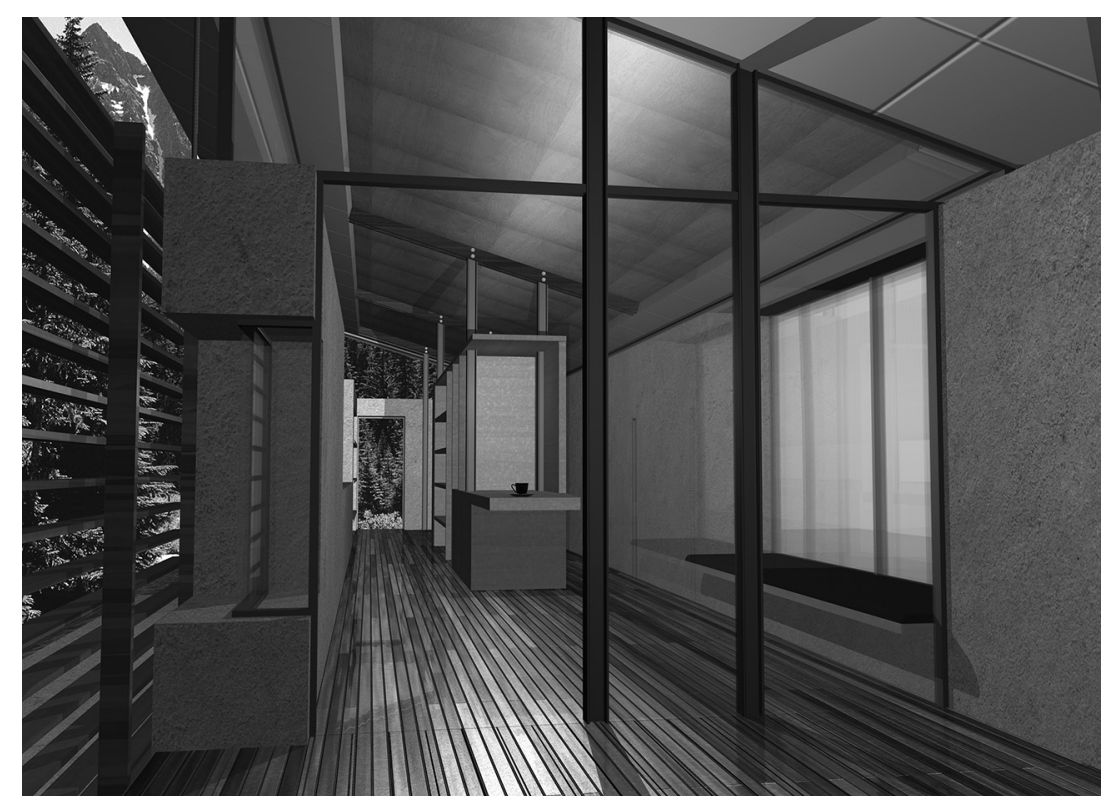

nterior rendering

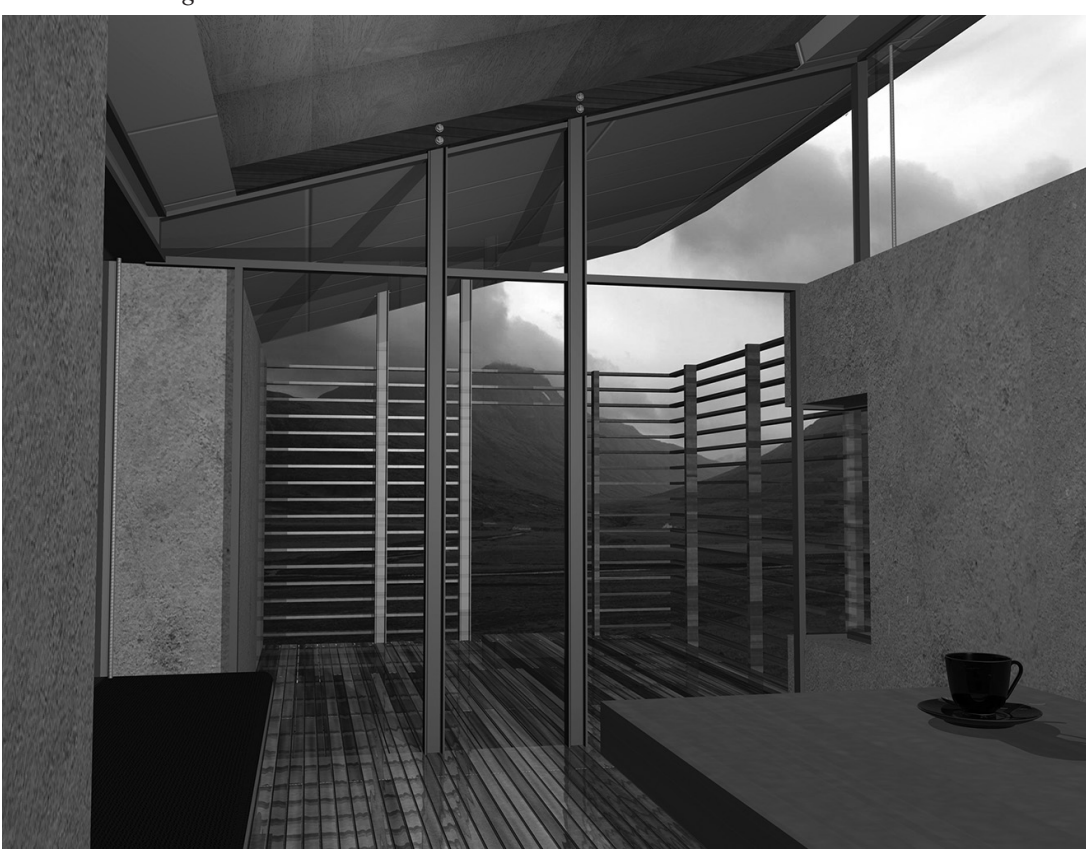



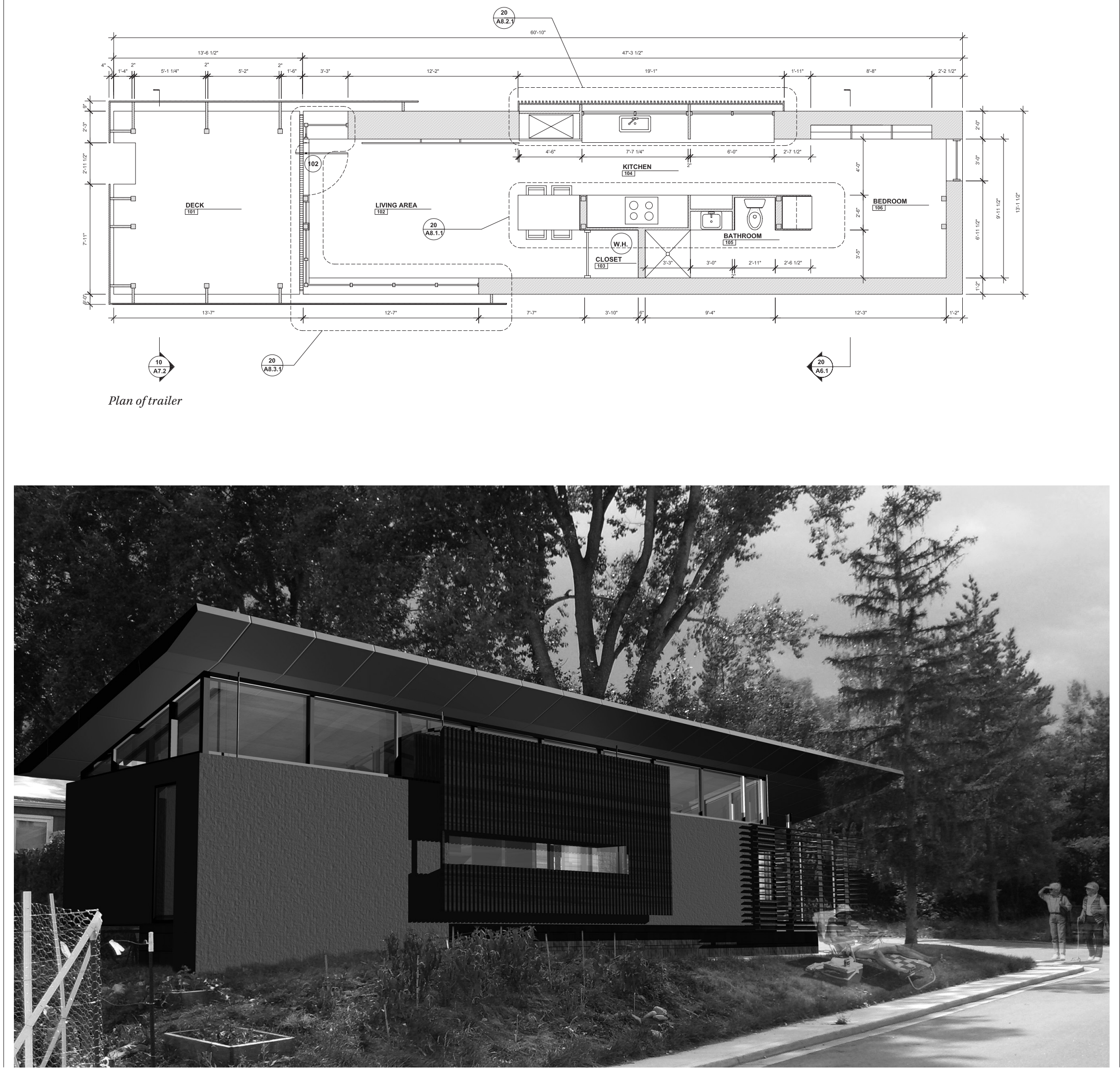
roof slopes to the south allowing for indirect lighting through the expanse of clerestory windows on the north elevation. The roof slope also provides advantageous solar orientation for the passive hot-water heating system.

TrailerWrap is collaboration involving a team of faculty and students in the College of Architecture + Planning; the Department of Physical Plan at the University of Colorado; the Children, Youth and Environments Center for Research and Design; the non-profit Thistle Community Housing; and the cooperative Mapleton Mobile Home Owner's Association in Boulder, Colorado. This collaborative effort aims to foster campus connections to the community and promote social justice. A tangible outcome will be a completed housing unit, meeting local codes and standards, which will be made available to a low-income household.

To date the TrailerWrap project has received significant financial support from a wide variety of community and university sources. A 1965 mobile home was donated by its previous owner and has been moved to a space in the Mapleton Mobile Home Park. The Thistle Community Housing group purchased this park in 2002 to ensure the long-term viability of affordable housing in Boulder Colorado and they have pledged $\$ 16,000$ toward the construction. Four grants supporting both the construction and project evaluation have been received from the Outreach Committee, Service Learning Committee, the Office of Diversity + Excellence, and the Institute for Ethical and Civic Engagement at the University of Colorado-Boulder. These grants, along with support from the Dean of the College of Architecture and Planning total approximately $\$ 31,000$, with $\$ 26,000$ earmarked for construction related expenses.

The pedagogy underlying the studio offers a unique opportunity for students interested in a comprehensive project-based, hands-on approach to architectural education that is engaged in a diverse spectrum of issues related to the act of making architecture. The emphasis on engaging architecture as an integrated endeavor provides the basis for a wide range of exploration into tectonic materiality, formal gymnastics, spatial landscapes, sustainable technologies, and community outreach. Specifically, the goal is to augment traditional design education with a curriculum based on collaborative, firsthand, full-scale, tactile immersion in a specific, cultural environment. The program utilizes a cross- disciplinary, research/design/build model designed to teach civic responsibility through culturally specific, environmentally responsible, and socially empowering lessons that engage underserved communities.

Students involved with the project draw upon the knowledge of skilled craftsmen in the electrical, plumbing, and metal working trades as they gain hands-on experience in the construction of an affordable housing utilizing sustainable building technologies, straw bale construction, passive and active solar energy, and material recycling. Working in the field, meeting with the city, interacting with the trades, and learning to confront/overcome logisti- cal hurdles in real time, students will encounter both the agony and ecstasy of making, and sometimes re-making, architecture at full-scale. This complex context provides a unique educational opportunity in which students are exposed to the act of construction as a fundamental component of critical design practice and civic engagement. We also expect that this course will increase students' awareness of unmet basic needs among the clients they serve and strengthen their sense of social responsibility, deepening their motivation for further civic engagement in their future professional development.
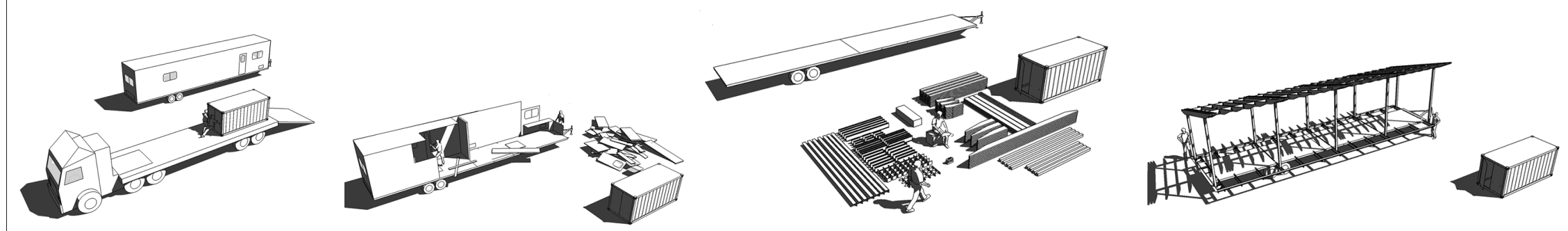